\title{
THE IMPLEMENTATION OF 2013 CURRICULUM IN ENGLISH TEACHING LEARNING AT MAN 1 PEKALONGAN
}

\author{
Nita Noviawati \\ Email:nnoviawati@gmail.com \\ Madrasah Aliyah Negeri 1 Pekalongan \\ Kedungwuni Timur, Indonesia
}

\begin{abstract}
This research was conducted with the aim to know and describe the implementation of 2013 curriculum in English teachinglearning at MAN 1 Pekalongan. Things done in this study include the implementation of teaching and learning activities, including constraints and actions related to teaching and learning activities at MAN 1 Pekalongan. The method used in this study is a case study on English teaching-learning by using 2013 curriculum at MAN 1 Pekalongan. The sample and place of research used in this study is an eleventh class, especially eleventh social 4class at MAN 1 Pekalongan. The source of data obtained by 1)Teaching-learning process by using 2013 curriculum; 2) The information involving the teacher and the students; 3)The documentation related to the implementation of 2013 curriculum. The results of this research can be concluded that many obstacles in the implementation of 2013 curriculum, such as the limited time on English teaching and learning activities, the facilities and infrastructure, and the assessment.
\end{abstract}

Keywords: An English Teaching , 2013 Curriculum

\section{INTRODUCTION}

In English subject at Madrasah level are generally taught include Listening, Speaking, Reading and Writing. It expected that the madrasah students are able to master English well. The success in English teaching learning process in madrasah can not be separated from several factors. They are : thediscipline, the persistence of learning,the student'smotivation to study, Hamzah (2013).

The quality of education is one factor that has a very important role, in this case the government always strives for improvements to the quality of education in Indonesia. The enactment of 2013 
Curriculum which is a refinement of Education Unit Level Curriculum (KTSP). The curriculum demands a paradigm shift in education and learning, especially on the type and level in formal education. These changes bring consequences for the teachers to implement of learning at the school in accordance with the curriculum. These learning changes to student centered learning whereas the previous curriculum the teacher centered learning, Hasbillah et.al (2016).

The substitution of curriculum is a problem that is always shadowing education in Indonesia. The curriculum is a difficult field to understand, but it open to discussion in discussion forums. The emphasis on character in 2013 curriculum expected to have a positive impact for students at MAN 1 Pekalongan to face challenges in the globalization era. According to Kunandar (2013), the authentic means the actual situation, namely the ability or skills possessed by thestudent. The use of authentic assessment because of it can provide solutions in describing improvements in student learning outcomes, observing, reasoning, trying and building networks.

In Putrayasa et al (2014) study, it was concluded that the implementation has been done in some schools but there are some obstacles in the application of the curriculum, one of them is the difference in 2013 curriculum with the previous curriculum. In general,the teachers assume that curriculum development is not teacher's job. A lack of understanding of the curriculum leads to the implementation of a non-ideal running curriculum. The teachers sometimes assume that the teacher's task only teaches materials in the classroom. The success of the implementation of 2013 curriculum in the schools is dependent on the participation of the teachers. The teacher knows the real condition of the students in the school. Based on the assumtion above, it can be concluded that the teacher has important role in the implementation of 2013curriculum because the teacher can know the difficulties or obstacles in the implementation of 2013 curriculum. The data can be used as input to the government to improve and find solutions for the perfection of 2013 curriculum. 


\section{RESEARCH METHODS}

This research is a type of case study research. This study is a detailed test of one event or event in the implementation of 2013 curriculum in English subject. Theplace of study conducted at Madrasah Aliyah Negeri 1 Pekalongan by taking sample eleventh social 4 class. Theimplementation of research in 2016/2017 Academic years for 4 months, from August to November 2016.

The data sources used for the excavation and data collection are: the processes of teaching and learning activities using 2013 curriculum; the informants, involving the teachers and the students ; the documentation, file and archives associated with 2013 curriculum instruments. The data collection techniques used are: observation to retrieve data in the form of events, in-depth interviews to retrieve data from informants, the document analysis to retrieve data in the form of documents.

The data analysis technique used is Milles and Huberman flow analysis. The analysis process can be done through three steps, as follows: the data reduction, the data presentation, and the conclusion.

\section{FINDINGS AND DISCUSSION}

In Pekalongan district, Madrasah Aliyah Negeri 1 Pekalongan is the target school for implementing the 2013 curriculum since 2014/2015 academic year. The first year of its implementation starts from tenth class, then second year applied in tenth and eleventh class.

The teachers who are in the tenth class have been through the training first.The training has given to the teachers who teach the subjects by using 2013 curriculum. The following year the training has given to the teachers who are in the eleventh, the training has given in turn. Theinterviews conducted on several teachers can be summarized that the training perceived as unhelpful in providing detailed description of the implementation of 2013 curriculum. On the other hand the teacher also believes that the implementation of 2013 curriculum seems very forced.The teacher's understanding about 2013 curriculum is very important, because teachers are the spearhead in the implementation of teaching in classroom. It feared that the implementation of 2013 curriculum would not be implemented 
properly if the teacher's understanding about 2013 curriculum has not been good. The application of 2013curriculum at MAN1 Pekalongan can be known from the following components.

1. RPP (Learning Implementation Plan).

David, (2010). Explain that one of the most important components in the implementation of learning is design. The instructional design is the design of learning. From the interviews it is known that the lesson plan of 2013 curriculum has changed from the previous curriculum. However, the content and outline of the lesson plan of 2013 curriculum with EducationUnit Leve Curriculum (KTSP curriculum) remains the same. In addition, the teachers prepare their own lesson plan derived based on the syllabus, as for the problems encountered that the format used in the English teacher discussion forum in Pekalongan with the existing format in the internet is a difference. The expectation of the English's teachers that they can use the same format of the lesson plan.

2. The Scientific Approach.

The results of the interview can be concluded, the scientific approach actually has been implemented in the previous curriculum. The previous curriculum did not use the term scientific approach. The process of observing, questioning, reasoning, organizing, and communicating has been done. That is related with the material explanations in the Teacher Training on Implementation 2013 Curriculum, although in practice it has not been organized.

On the other hand, the teachers argue that the scientific approach can not be applied fully. The teachers more focused on achieving the learning objectives and the materials can beunderstood well by thestudents. The student'sactivity in the learning process has not been met fully, because of not all students are active in learning process. The implementation of 2013 curriculum expected that students can balance and adjust in the learning process in accordance with 2013 curriculum. 
3. The Learning Method

In 2013 curriculum, the learning process is not only done in the classroom but the learning process can also be done outside of the classroom. The applications of it can be done by looking at the conditions and time. Some teacher have implemented learning outside the classroom to overcome the boredom of the students if it done in the classroom continuously. On the other hand there are teachers who do learning process activities for the time being still done in the classroom.

4. The Media Learning

Based on the interview, that learning media often used by the teachers are LCD projector, audio visual and supporting text. In MAN 1 Pekalongan already provides LCD in each class. The other supporting media used in the learning process are books, newspapers, magazines, display aids and internet. The selection of learning media has done by the teachers adjust the materials taught so that students can understand well.

5. The Learning Resources

In the first year of application of 2013 curriculum, the manual book still needs to be improved, both on the content and on the writing. The application of 2013 curriculum in the second year, the manual book has been revised. The results of the revisions have been good although there are some submissions.

6. The Assessment

The assessment is the most important thing, that is not separated in the education system. The improvementof education quality can be seen from the values which obtained by the students. The result of the interview, found that the implementation of 2013 curriculum in MAN 1 Pekalongan in the first year found some obstacles such as about assessment. The assessments have done but it just several thing.In the second year, the implementation of 2013 curriculum in MAN 1 Pekalongan, especialy on the assessment have all done. 


\section{OBSTACLES IN THE APPLICATION OF 2013 CURRICULUM IN MAN 1 PEKALONGAN}

In this research, the obstacles faced by English teachers in MAN 1 Pekalongan, such as:

\section{Time}

The learning process in MAN 1 Pekalongan constrained by the time. In the previous curriculum, English teaching and learning are four hours lesson in a week, while in 2013 curriculum English teaching and learning are two hours lesson in a week. The reduction lesson time on teaching and learning English process is very impact on the students so they can not understand material well.

2. The Facilities and Infrastructure

Sagala (2003), said that the significance of learning supported by the adequate facilities and infrastructure. Based on the results of interviews, student books on the first print is still less than perfect. The lack of the student book can be seen on the content of books, the punctuation and the writing errors. While the material on the book is still not in accordance with the syllabus, in addition there are also some material that does not exist. The solution of the material disquiet then the teacher must adjust the book with the syllabus and equip it with the material itself. Another obstacle is the readiness of the LCD projector in the teaching learning process, because many LCD proyector have broken at MAN 1 Pekalongan.

3. Assessment

In the first semester, the implementation of 2013 curriculum at MAN 1 Pekalongan has carried out several assessments, including self assessment, peer assessment, portofolio assessment, written assessment, journal and observations. For the assessment of other elements will be carried out over time. The constraints of the assessment are when the process of giving the material, the teacher also must give behavior's student assessment.It made the teacher less focused on teaching learning process.Many documentation of the assessment that must be made by teachers, it feared that not at all assessment have done by the teacher. 
4. The Student's activity in Teaching and Learning Process Based on the interview, the student activity in MAN 1 Pekalongan has not been active overall. The classes that have active students only on certain lessons and it just some student. The problem of student's activeness influenced by the different characters each student. The passive students is the students who taciturn and timid.

\section{EFFORTS TO OVERCOME OBSTACLES ON APPLICATION OF 2013 CURRICULUM IN MAN 1 PEKALONGAN}

The followings are the efforts made by the English teacher in MAN 1 Pekalongan to overcome the obstacles:

1. The Efforts toOvercome the Time Constraints

To fulfill the completeness of the documentation in 2013 curriculum, among others: Learning Planning, Learning Process and Assessment need enough time. The solutions that English teacher of MAN 1 Pekalongan are seeking are: (1) The teacher prepares planned administration,Lesson plan, Annual Program, Semester Program, Assessment Rubric, Assessment Guidance, etc. The teachers' administrative documentation is completed at home. (2) Making lesson plan has done at home. It spent rest time at home because it is not possible to make lesson plan in the school. (3)The constraints in the teaching learning process, teachertried to give assignments and work to the students. (4) The teacher's solution in overcoming the time constraints in the assessment is done by looking at the conditions and situations in the classroom. If it is not possible to give individual assessment, the teacher will conduct a group assessment. The assessment by English teacher at MAN 1 Pekalongan is not only in the classroom but also the assessment outside the classroom.

2. The Efforts to Overcome from the limitations of facilities and infrastructure

The limited facilities and infrastructure in MAN 1 Pekalongan quite disturb the process of teaching and learning English. The basic competence demands that must use technology in the 
teaching learning process, but with the limitation on existing facilities and infrastructure in MAN Pekalongan can affect the disruption of the teaching learning process. In consequencythe process of the student's assessment is not maximal.

The teacher's creativity in overcoming the problem is very needed, English teacher at MAN 1 Pekalongan has tried to overcome the problems that are exposed above by: the English teaching learning process has done in language laboratory, the other teacher bring LCD projector portable for use in learning process in the classroom at MAN 1 Pekalongan. As an alternative effort by giving tasks to thestudents to browse English learning materials on the internet.

3. The Efforts to Overcoming the Assessment's Obstacle Through interviews, it is known that English teachers have difficulty in making assessment rubric. The efforts are made to overcome this problem by creating and discussing the assessment rubric in the discussion betweem English teacher forum for joint use. The teacher reads the book from various references on the assessment to increase knowledge. The other alternative efforts to overcome the problem of assessment is to make plans and descriptions which appropriate to the students.

The number of assessment elements in2013 curriculum must be assessed by assessing one by one and looking at possible conditions at the time of the assessment. The peer assessment carried out before the written test whereas in the portfolio assessment carried out by assigning tasks to learners and collected into a task book. Theproject assessment gave to the students grouply which done outside the lesson. The efforts that has been exposed above has been done by English teachers at MAN 1 Pekalongan to implement the implementation of 2013 curriculum. It is expected that all efforts that have been done can give positive impact for students. The others unresolved constraints are still process of finding the right solution.

4. The Student's Activities in Teaching and Learning Process The activity of the student's in teaching and learning process depends on the ability and individual characters of the students. 
The plurality of students characters made the English teachers at MAN 1 Pekalongan always give motivation to students to be more active. Themotivation is given in order to increase students' confidence.

From the interview, the teachers need to provide stimulants to the students who quiet or shy to be more confident when talking in front of the forum or class. In addition, the teachers can also provide praise and value addition for students who are active in teaching learning process. The teachers try to make thestudents to be able to express themselves in front of the class is not an easy, it need apropriate methods to the conditions in the classroom. Thediscussion method is considered more appropriate with the condition of the class. The students to be more active in the discussion with the group, active seek data and learn independently and brave to convey the results of the discussion in front of the class.

The group discussion considered as the space of the students to expres their opinion. The students can do interaction and discussion each other confidently. The achievements that have been achieved in the group discussion can be used by theteacher to improve the teaching and learning English in MAN 1 Pekalongan.

\section{CONCLUSION}

In this study it can be concluded that the implementation of 2013 curriculum in English teaching learning process in MAN 1 Pekalongan should be accompanied by readiness of data or supporting documents in the 2013 curriculum, such as :lesson plan and syllabus, the scientific approach in the teaching learning process, and use of supporting media such as LCD projectors, learning resources. It should be prepared and strived to the best possible for the achievement of the objectives of the teaching learning process properly.

Also, the 2013 curriculum has the goal of students to be more characterized and independent, but with the diversity of students's characters the suitable approaches needed, so the students can be motivated to be more active in following the learning process. Many 
documentation of data files and assessment elements that must collected by English teachers in MAN 1 Pekalongan made theEnglish teachers should be able to find the best solution to fulfillment of the data files and assessment completely without forgetting the achievement of learning objectives to the students.

\section{REFERENCES}

Arikunto, S. (2002). Prosedur Penelitian: Suatu Pendekatan Praktek. Jakarta: PT. Rineka Cipta.

Bintari, N. L. G. R. P., Sudiana, I. N., \& Putrayasa, I. B. (2014). Pembelajaran Bahasa Indonesia Berdasarkan Pendekatan Saintifik (Problem Based Learning) Sesuai Kurikulum 2013 di Kelas VII SMP Negeri 2 Amlapura. Jurnal Pendidikan Bahasa, 3(1).

Brown, H.D. (2004). Language Asessment. San Francisco: San Francisco University Press.

Boyce, B Ann. (2003). Improving Your Teaching Skills. New York: Mc Graw Hill Higher Education.

Cheung, M. Y. M. (1999). The process of innovation adoption and teacher development. Evaluation \& Research in Education, 13(2), 55-75.

Christensen, L.B. (2001). Experimental Methodelogy. Massachusset: Allyn and Baco.

Emmer, E.T. et al. (1984). Classroom Management for Secondary Teachers. New Jersey: Prentice-Hall Inc Englewood Cliffs.

Hamzah. (2007). Manajemen Teori Praktek dan Riset Pendidikan. Cetakan ke 1. Jakarta: Bumi Aksara.

Harmer, J. (2004). The Practice of English Language Teaching. London: Longman Group UK Limited.

Hasbillah, et. al. (2016). Model Pembelajaran Kooperatif Dalam Kurikulum 2013. Prosiding Seminar Nasional Pendidikan Dasar 2016. ISBN 978-602-1150-16-0. Malang.

Kunandar. (2013). Penilaian Authentik (penilaian hasil belajar peserta didik berdasarkan kurikulum 2013). Jakarta: PT. Raja Grafindo Persada. 
Meriwether, G. (1998). Introduction a Process Approach in The Teaching of Writing in a Lower Primary Classroom. English Teachers' Journal. Pp. 64.

Nagaraj, G. (1996). English Language Teaching: approaches, methods, technique. London: Sangam Books Ltd.

Nunan, D. (1992). Research Methods in Language Learning. Cambridge: Cambridge University Press.

Hornby, A.S. (1995). Oxford Advanced Learner's Dictionary. Oxford University Press.

Saleh, M. (2001). Pengantar Praktek Penelitian Pengajaran Bahasa. Semarang: IKIP Semarang Press.

Sugiyono. (2015). Metode Penelitian Kuantitatif, Kualitatif dan R\&D. Bandung: Alfabeta.

Sutama. (2015). Metode Penelitian Pendidikan. Surakarta: Fairuz Media.

Wragg, E.C. (1994). An Introduction to Classroom Observation. New York: Routledge. 